\title{
Front Matter: Volume 11382
}

, "Front Matter: Volume 11382," Proc. SPIE 11382, Smart Structures and NDE for Industry 4.0, Smart Cities, and Energy Systems, 1138201 (5 June 2020); doi: $10.1117 / 12.2572673$

SPIE. Event: SPIE Smart Structures + Nondestructive Evaluation, 2020, Online Only 


\section{PRO CEEDINGS OF SPIE}

\section{Smart Structures and NDE for Industry 4.0, Smart Cities, and Energy Systems}

Kemie Gath

Norbert G. Meyendorf

Editors

27 April - 8 May 2020

Online Only, United States

Sponsored by

SPIE

Cooperating Organizations

J et Propulsion Laboratory (United States)

Published by

SPIE

Volume 11382 
The papers in this volume were part of the technical conference cited on the cover and title page. Papers were selected and subject to review by the editors and conference program committee. Some conference presentations may not be available for publication. Additional papers and presentation recordings may be available online in the SPIE Digital Library at SPIEDigita lLibrary.org.

The papers reflect the work and thoughts of the authors and are published herein as submitted. The publisher is not responsible for the validity of the information or for any outcomes resulting from reliance thereon.

Please use the following format to cite material from these proceedings:

Author(s), "Title of Paper," in Smart Structures and NDE for Industry 4.0, Smart Cities, and Energy Systems, edited by Kerrie Gath, Norbert G. Meyend orf, Proc eedings of SPIE Vol. 11382

(SPIE, Bellingham, WA, 2020) Seven-digit Article CID Number.

ISSN: 0277-786X

ISSN: 1996-756X (electronic)

ISBN: 9781510635418

ISBN: 9781510635425 (electronic)

Published by

SPIE

P.O. Box 10, Belling ham, Washington 98227-0010 USA

Telephone +1 3606763290 (Pa cific Time)· Fax +1 3606471445

SPIE.org

Copyright $(2020$, Society of Photo-O ptic al Instrumentation Engineers.

Copying of material in this book for intemal or personal use, or for the intemal or personal use of specific clients, beyond the fair use provisions granted by the U.S. Copyright Law is a uthorized by SPIE subject to payment of copying fees. The Transactional Reporting Service base fee for this volume is $\$ 21.00$ per article (or portion thereof), which should be paid directly to the Copyright Clearance Center (CCC), 222 Rosewood Drive, Danvers, MA 01923. Payment may also be made electronically through CCC Online at copyright.com. Other copying for republication, resale, advertising or promotion, or any form of systematic or multiple reproduction of any material in this book is prohibited except with permission in writing from the publisher. The CCC fee code is 0277 $786 \mathrm{X} / 20 / \$ 21.00$.

Printed in the United States of America by Curran Associates, Inc., und er license from SPIE.

Publication of record for individual papers is online in the SPIE Digital Library.

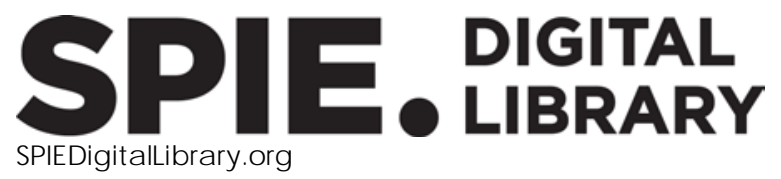

Paper Numbering: Proceedings of SPIE follow an e-First publication model. A unique citation identifier (CID) number is assigned to each article at the time of publication. Utilization of CIDs allows articles to be fully citable as soon as they are published online, and connects the same identifier to all online and print versions of the publication. SPIE uses a seven-digit CID article numbering system structured as follows:

- The first five digits correspond to the SPIE volume number.

- The last two digits indicate publication order within the volume using a Base 36 numbering system employing both numerals and letters. These two-number sets start with $00,01,02,03,04$, 05, 06, 07, 08, 09, 0A, 0B ... 0Z, followed by 10-1Z, 20-2Z, etc. The CID Number appears on each page of the manuscript. 


\section{Contents}

\section{SENSORS, ADAPIIVE STRUCTURES, AND ARTIRCIALINTEUGENCE}

$1138202 \quad$ Numerical validation using finite element to assess the performance of microwave sensor in detecting blade tip displacement [11382-1]

1138203 Deep leaming-based crack detection in a concrete tunnel structure using multispectral dynamic imaging [11382-2]

1138204 High energy laser detection through themoelectric generators [11382-3]

1138205 Water pipe valve detection by using deep neural networks [11382-4]

\section{CHARAC TRIZATION OF MATRIALS FOR ENRGY SYSTEMS}

1138206 Design of passive acoustic hyperbolic-shaped filter for nonlinear ultrasonic inspection method optimisation [11382-5]

1138208 Cement properties with embedded sensors for wellbore integrity monitoring [11382-8]

\section{DEVELOPMENT AND APPUCATION OF SMARTMATIRIALS FOR ENGRG SYSTIMS}

11382 OB MetaSub piezoelectric energy harvesting [11382-12]

NDEAND SHM OF ENERGY SYSTEMS

11382 OC Meso-scale piezoelectric energy havester for low-frequency rotational motion [11382-13]

11382 OD Nondestruc tive evaluation of nuclear spent fuel dry cask structures using non-contact ACF SDV Lamb wave method [11382-14]

\section{BIG DATA MANAGEMENTAND PROCESSING}

11382 OG Artificial neural network approach to improve the performance of battery and themal storage [11382-18] 
REALTIME MONTORING OFTHE SMARTFACTORY SYSTEMS AND SUBSYSTEMS

$11382 \mathrm{OH} \quad$ Laser based remote and rapid inspection for composite plates [11382-19]

11382 이 Preliminary investigation of a differential pressure sensor using flexible piezoelectrics with pyroelectric compensation [11382-21]

11382 0] Investigation on the relationship between wave propagation speed and vibration frequency in concrete floors using nonlinear regression model [11382-22]

POSTER SESSION

1138200 Study on the temperature effect of conc rete continuous beam bridge [11382-32]

$113820 Q$ The research and application of a self-monitoring intelligent reinforcement system for metal roof panel [11382-33]

11382 OS Heat loss detection using themal imaging by a small UAV prototype [11382-34]

11382 OU Design of dynamic building information system based on structural health monitoring information [11382-35]

SMARTCITY AND INTEUGGNTTRANSPORIATION ECOSYSIEM ENABLRS

11382 OV Auxetic cantilever beam energy havester[11382-29]

11382 0X Projection/ interactive surface opportunities in smart vehic les [11382-30]

POSTER SESSION

11382 oY Feature recognition and detection for road damage based on intelligent inspection teminal [11382-37]

$113820 Z$ Research on smart clock synchronization method based on GPS for seismic data acquisition and recording system [11382-38]

1138211 Comosion monitoring and evaluation of steel strand for tansmission line based on fiber Bragg grating (FG) [11382-40]

1138212 Acoustic emission monitoring of the fracture behavior of motar specimens fabricated using recycled concrete aggregates [11382-42]

1138213 Comelation between acoustic emission parameters and fracture behavior of repaired marble specimens [11382-43] 
1138214 Monitoring a model cable-stay bridge structure by acoustic emission and laser Doppler vibrometry [11382-44]

1138215 Monitoring of modified fine recycled concrete aggregate for mortarproduction by ultrasound [11382-45]

1138219 Development of selfsensing cementitious materials [11382-49] 
Proc. of SPIE Vol. 11382 1138201-6

\section{Downloaded From: https://www.spiedigitallibrary.org/conference-proceedings-of-spie on 26 Apr 2023
Terms of Use: https://www.spiedigitallibrary.org/terms-of-use}

